\title{
Conventional PCR for detection of Corynespora cassiicola in soybean seeds ${ }^{1}$
}

\author{
Marcella Viana de Sousa ${ }^{2}$, Carolina da Silva Siqueira ${ }^{3 *}$, José da Cruz Machado ${ }^{3}$
}

\begin{abstract}
The fungus Corynespora cassiicola, causal agent of target spot in soybeans, can be transmitted by soybean seeds and as of that point cause severe damage. This disease may be diagnosed at an early stage by seed testing, but knowledge in this area is insufficient. Because of that and increased attack by the disease in soybean areas in Brazil, further studies are required. The aim of this study was to evaluate the use of conventional PCR in detecting C. cassiicola in soybean seeds. The GA4-F/GA4-R primers described in the literature were tested for their specificity and sensitivity for detection of $C$. cassiicola in pure culture and in soybean seeds. Uninoculated and inoculated seed samples were used with different incidence levels $100 \%, 10 \%, 1 \%, 0.5 \%, 0.25 \%$, and $0 \%$ of preestablished inoculum potentials, $\mathrm{P} 0, \mathrm{P} 1, \mathrm{P} 2$, and $\mathrm{P} 3$. Detection of C. cassiicola in P1 inoculum potential was observed in samples with incidence levels of $10 \%$ to $100 \%$. In the P3 potential, detection of the pathogen was successful in samples at the low level of $0.25 \%$.
\end{abstract}

Index terms: seed pathology, target spot, electrophoresis.

\section{Uso de PCR convencional para a detecção de Corynespora cassiicola em sementes de soja}

\begin{abstract}
RESUMO - O fungo Corynespora cassiicola, agente causal da mancha alvo em soja, pode ser transmitido por sementes de soja e a partir daí causar danos severos. A diagnose precoce desta doença pode ser realizada por meio de testes de sementes, cujo conhecimento é insuficiente. Por esta razão e pelo aumento da área de soja atacada pela referida doença no Brasil, estudos mais aprofundados são necessários. Neste trabalho, o objetivo foi avaliar o uso da técnica PCR convencional na detecção de $C$. cassiicola em amostras de sementes de soja. Os primers GA4-F/GA4-R, relatados na literatura, foram testados para verificar a sua especificidade e sensibilidade para detecção de $C$. cassiicola em cultura pura e em sementes de soja. Foram utilizadas amostras de sementes, inoculadas e não inoculadas, com diferentes níveis de incidência, de 100\%, 10\%, 1\%, 0,5\%, 0,25\% e $0 \%$, por potenciais de inóculo preestabelecidos, P0, P1, P2 e P3. A detecção de C. cassiicola no potencial de inóculo P1, foi observada em amostras com níveis de incidência de $10 \%$ a $100 \%$. No potencial P3, a detecção do patógeno foi bem-sucedida em amostras com nível mínimo de 0,25\%.
\end{abstract}

Termos para indexação: patologia de sementes, mancha alvo, eletroforese.

\section{Introduction}

The fungus Corynespora cassiicola (Berk. and M.A. Curtis) C.T. Wei, etiological agent of soybean target spot, can be found on leaves, petioles, stems, pods, and seeds and can cause estimated damages of $20 \%$ to $40 \%$ in the field (Almeida et al., 2005; Koenning and Creswell, 2006). The fungus is cosmopolitan and abundant in tropical regions (Kaushal, 2009) and is found in diverse soybean growing regions in Brazil. This fungus is an organism that can survive in crop residue, volunteer plants and seeds, and its survival is favored by relative humidity conditions of $80 \%$ and temperatures from $20{ }^{\circ} \mathrm{C}$ to $30{ }^{\circ} \mathrm{C}$ (Henning et al., 2005; Soares et al., 2009). It is spread mainly by wind, spattering of rain (Almeida et al., 2005), and infected or contaminated seeds (Sinclair and Backman, 1989).

Detection of phytopathogens in seeds has become increasingly important, especially because of the relevance of this measure as part of plant health management (Sajeesh et al., 2014). For detection of C. cassicola in soybean seeds, the method used is based on incubation of seeds in a paper substrate (Brasil, 2009b), known as blotter test. This method can pose limitations through difficulties in recognizing

${ }^{1}$ Submitted on 07/14/2015. Accepted for publication on 03/21/2016.

${ }^{2}$ Empresa Monsanto, Uberlândia, MG, Brasil.

${ }^{3}$ Departamento de Fitopatologia, UFLA, Caixa Postal 3037, 37200-000 - Lavras, MG, Brasil.

*Corresponding author $<$ kerolpet@gmail.com $>$ 
morphological characteristics, such as those of the fungus in question, which has variation in the color and growth of colonies (Sousa and Bentes, 2014). In a study comparing the blotter test and molecular test for detection of Alternaria spp. in carrot seeds, Konstantinova et al. (2002) directed attention to the delay in identification of the pathogen by the blotter test and the impossibility of identification of any other pathogen that does not produce important morphological characteristics like conidia, indicating the molecular test as an alternative for resolving this impasse.

Walcott (2003) compared molecular and morphological tests and reaffirmed the potential for use of molecular techniques for detection of pathogens associated with seeds. Organizations responsible for seed analyses are attentive to recent molecular techniques, especially in regard to the benefits they offer in terms of precision and agility (Molouba et al., 2001; Sajeesh et al., 2014). Through the polymerase chain reaction (PCR) technique, conventional and/or quantitative, pathogens were successfully detected in seeds by molecular means in the pathosystems Fusarium oxysporum f. sp. phaseoli in common bean seeds (Sousa et al., 2015), Colletotrichum lindemuthianum in common bean seeds (Chen et al., 2007, 2013), Sclerotinia sclerotiorum in soybean seeds (Botelho et al., 2015), Rhynchosporium secalis in barley seeds (Ríos et al., 2007), Peronospora variabilis in quinoa (Testen et al., 2014), and Macrophomina phaseolina in slender amaranth (Biswas et al., 2013), among others.

The aim of this study was to evaluate the use of the conventional PCR technique in detection of C. cassiicola in soybean seed samples.

\section{Materials and Methods}

\section{Origin of isolates and maintenance of fungal cultures}

The isolates of $C$. cassiicola were obtained from symptomatic soybean plants; after their identity was confirmed, they were deposited in the Mycological Collection of the Seed Pathology Laboratory (Coleção Micológica do Laboratório de Patologia de Sementes - CMLAPS) of the Federal University of Lavras (UFLA), Lavras - MG, Brazil, and were stored for approximately three months (Table 1). Disks measuring $5 \mathrm{~mm}$ of all the fungal cultures used in this study were transferred to Petri dishes containing PotatoDextrose-Agar medium prepared according to manufacturer instructions (PDA, Acumedia, Lansing, MI) and kept under incubation at a temperature of $25 \pm 2{ }^{\circ} \mathrm{C}$ and $12 \mathrm{~h}$ photoperiod for seven days. After development of the colonies of all the fungi, part of the mycelium was scraped off the surface using a surgical scalpel and then placed in microtubes for storage in an ultrafreezer $\left(-80^{\circ} \mathrm{C}\right)$ up to the time of the test.

Table 1. Isolates used for sensitivity and specificity tests of primers for detection of Corynespora cassiicola in soybean seeds.

\begin{tabular}{llcc}
\hline \multicolumn{1}{c}{ Pathogen } & Code & Isolation & Place of origin \\
\hline C. cassiicola & CMLAPS 312 & Soybean seeds & EMBRAPA / PR \\
C. cassiicola & CMLAPS 461 & Soybean seeds & Rio Verde / GO \\
C. cassiicola & CMLAPS 462 & Soybean seeds & Rio Verde / GO \\
C. cassiicola & CMLAPS 464 & Soybean seeds & Rio Verde / GO \\
C. cassiicola & CMLAPS 465 & Soybean seeds & Rio Verde / GO \\
C. cassiicola & CMLAPS 466 & Soybean & Inst. Phytus / RS \\
C. cassiicola & CMLAPS 467 & Soybean & Inst. Biológico / SP \\
Colletotrichum truncatum & CMLAPS 327 & Soybean seeds & Ibia / MG \\
Cercospora kikuchi & CMLAPS 358 & Soybean seeds & UFLA / MG \\
Phomopsis sojae & CMLAPS 484 & Soybean stem & UFLA / MG \\
\hline
\end{tabular}

\section{Seed preparation and inoculation}

Soybean seeds (M7110-IPRO, Monsoy ${ }^{\circledR}$ ) with incidence of $8 \%$ of Aspergillus sp., $9 \%$ of Penicillium sp, and germination of $98 \%$ of normal seedlings (Brasil, 2009a, 2009b) were disinfected on the surface with $2 \%$ sodium hypochlorite for $1 \mathrm{~min}$, followed by washing $(2 \mathrm{x})$ in distilled and sterilized water and drying for 48 hours. These seeds were inoculated separately with the isolate of $C$. cassiicola, LAPS 312 , by osmotic priming (Machado et al., 2012). In this method, seeds are placed in direct contact with the fungal colonies that were previously developed in PDA medium, with water potential adjusted to -1.0 MPa for five days, as recommended by the software SPPM (Michel and Radcliffe, 1995) in $15 \mathrm{~cm}$ diameter Petri dishes. The periods of contact of the seeds with the fungal cultures, in BOD incubators at the temperature of $25 \pm 2{ }^{\circ} \mathrm{C}$ and $12 \mathrm{~h}$ photoperiod, were $0,36,72$ and 108 hours, corresponding to the inoculum potentials of P0, P1, P2 and P3. After that, the seeds were dried for 48 hours at a temperature 
of approximately $23^{\circ} \mathrm{C}$ for later mixture with healthy seeds.

To determine the sensitivity for detection of the fungus C. cassiicola when associated with soybean seeds by means of the conventional PCR technique, 400 seed lots were prepared by mixing artificially inoculated seeds (within each inoculum potential evaluated), disinfected with $1 \%$ sodium hypochlorite for 1 minute, with non-inoculated seeds, generating differentiated incidence levels (IL), which were: $100 \%, 10 \%, 1 \%, 0.5 \%, 0.25 \%$ and $0 \%$.

Evaluation of specificity and sensitivity to detection of C. cassiicola in pure culture

The mycelium of $C$. cassiicola isolates and of other species pathogenic to soybean, which were stored in advance, had DNA extracted by the Wizard ${ }^{\circledR}$ Genomic DNA Purification kit (Promega, Madison, WI) according to manufacturer instructions.

The specific primers used for detection of C. cassiicola in leaves, previously reported in the literature by Dixon et al. (2009), GA4-F/GA4-R, and Silva et al. (1998), ITSA/ITSB, were tested and adjusted, initially in silico for detection of this pathogen in soybean seeds, taking sequences of genes deposited in the Genbank $^{\circledR}$ (http://www.ncbi.nlm.nih.gov). After optimization of the primers in pure culture of the isolates, tests were carried out for determination of the specificity for $C$. cassiicola in conventional PCR in relation to other fungi commonly associated with soybean seeds, such as Colletotrichum truncatum, Cercospora kikuch and Phomopsis sojae (Table 1). Amplification was carried out with the Platinum ${ }^{\circledR}$ Taq DNA polymerase kit (Promega); $25 \mu 1$ of the reaction contained: 1x PCR Buffer, $10 \mathrm{mM}$ dNTP mix $(2.5 \mathrm{mM}$ of each dNTP), $50 \mathrm{mM} \mathrm{MgCl}, 10 \mu \mathrm{M}$ of each primer, $2.0 \mu \mathrm{l}$ of DNA (20 ng), $1 \mathrm{u} / \mu \mathrm{l}$ of Platinum Taq DNA polymerase and ultrapure water.

Amplification consisted of initially denaturation of $94{ }^{\circ} \mathrm{C}$ for 5 minutes and 30 cycles of denaturation of $94{ }^{\circ} \mathrm{C}$ for 30 seconds, annealing of $58.5^{\circ} \mathrm{C}$ for 30 seconds and extension of $72{ }^{\circ} \mathrm{C}$ for 45 seconds, with final extension of $72{ }^{\circ} \mathrm{C}$ for 5 minutes. A $5 \mu$ laliquot was used to separate the PCR products in $1.2 \%$ agarose gel, stained with Gel Red (Biotium), with electrophoretic run carried out at $120 \mathrm{~V}$.

After testing, the pair of primers selected, designed by Dixon et al. (2009), was checked in regard to its sensitivity through dilution series (10x), which were from $20 \mathrm{ng}$ to 20 fg of the total genomic DNA of $C$. cassiicola. The primers of Silva et al. (1998) were not capable of detecting only $C$. cassiicola and, therefore, they were not used for the part of detecting the incidence levels in seeds.

Detection of C. cassiicola in artificially infected soybean seeds

The soybean seeds artificially inoculated by the isolate
LAPS 312 at each incidence level $(100 \%, 10 \%, 1 \%, 0.5 \%$, $0.25 \%, 0 \%$, represented by the inoculum potentials $\mathrm{P} 0, \mathrm{P} 1$, P2 and P3, were ground separately in a blender containing liquid nitrogen, until obtaining a fine powder. Between each grinding of the samples, which went from the lower inoculum potential to the higher, the blender was sterilized with $1 \%$ sodium hypochlorite for 2 minutes and washed with running water, thus avoiding any type of contamination between samples. For DNA extraction, 50 milligrams of ground seeds were removed for each one of the 3 replications. Immediately after maceration, the DNA of each sample was extracted separately with DNeasy ${ }^{\circledR}$ Plant Mini Kit (QIAGEN), following the protocol of the manufacturer. The quality of the DNAs was observed in $1 \%$ agarose gel in $0.5 x \mathrm{TBE}$ (40 mM Tris-borate, 1 mM EDTA, pH 8.0) buffer, stained with Gel Red (Biotium), and visualized under UV light. The DNA was quantified in the Nano Drop 3300 spectrophotometer (Thermo Scientific).

Amplification was carried out with the more specific primers in accordance with the results shown in the specificity test. The kits and the amplification cycles were the same as described above.

Detection of C. cassiicola in naturally infected soybean seeds

Seeds of two soybean cultivars naturally infected by $C$. cassiicola (Table 2), coming from plants with symptoms of target spot, were sent from Mato Grosso (Fundação MT, Rondonópolis) for detection and confirmation of the presence of the pathogen through conventional PCR using the specific primers tested.

Table 2. Seeds from two cultivars naturally infected with isolates of Corynespora cassiicola.

\begin{tabular}{cccc}
\hline Sample & Isolate & Cultivar & Crop Season \\
\hline 1 & FMT022 & TMG1180 & $2014 / 14$ \\
2 & FMT022 & TMG1176 & $2014 / 14$ \\
3 & FMT049 & TMG1180 & $2014 / 14$ \\
4 & FMT049 & TMG1176 & $2014 / 14$ \\
5 & FMT055 & TMG1180 & $2014 / 14$ \\
6 & FMT055 & TMG1176 & $2014 / 14$ \\
7 & FMT058 & TMG1180 & $2014 / 14$ \\
8 & FMT058 & TMG1176 & $2014 / 14$ \\
9 & FMT053 & TMG1180 & $2014 / 14$ \\
10 & FMT053 & TMG1176 & $2014 / 14$ \\
11 & FMT059 & TMG1180 & $2014 / 14$ \\
12 & FMT059 & TMG1176 & $2014 / 14$ \\
\hline
\end{tabular}

Before the extractions of DNA, the seeds naturally infected were incubated for 7 days in PDA medium with manitol (-1.0 MPa) to increase the biomass of the pathogen present, thus enabling its detection in PCR (BIO-PCR). 


\section{Results and Discussion}

The DNA extracted from positive controls (pure cultures of C. cassiicola) and negative controls (other fungal species pathogenic to soybean) were analyzed by Nano Drop 3300 (Thermo Scientific) and electrophoresis gel and exhibited sufficient quantity and purity.

Studies indicated that the pair of primers GA4-F/GA4-R, designed by Dixon et al. (2008), was specific for detecting $C$. cassiicola (Figure 1). The other species of fungi pathogenic to soybean were not amplified in all the replications according to electrophoretic analysis of the DNA fragments obtained with PCR.

In the detection limit test with DNA from pure cultures of $C$. cassiicola (Figure 2), greater sensitivity was observed on the part of the primers for detection of the isolate LAPS 312. Detection was possible up to the concentration of $0.2 \mathrm{ng}$ of DNA.

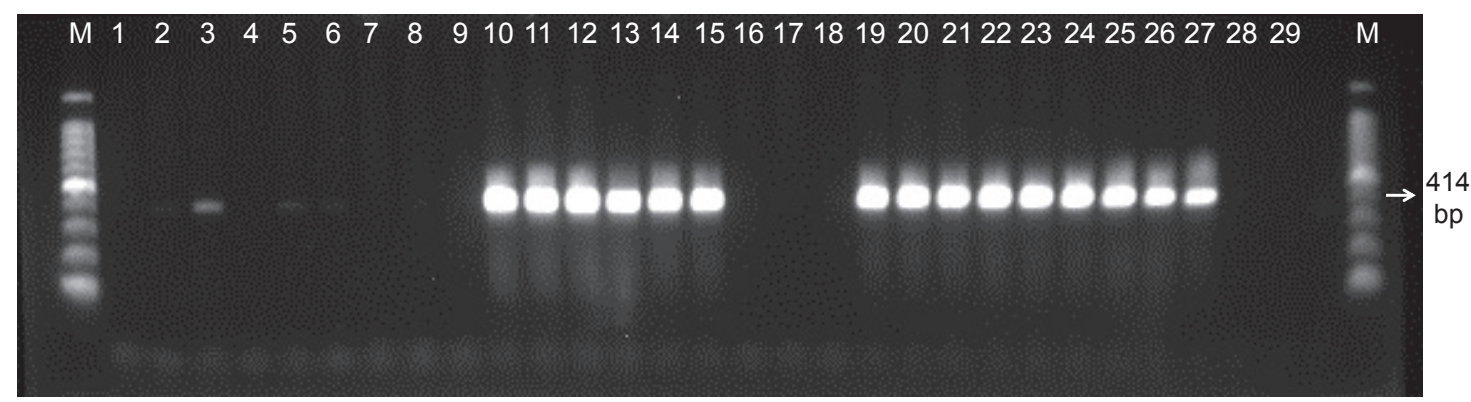

Figure 1. Specificity of the pair of primers GA4-F/GA4-R. Lines 1-2: Colletotrichum truncatum; lines 4-6: Cercospora kikuchi; lines 7-9: Phomopsis sojae. Isolates of $C$. cassiicola lines 11-12: CMLAPS 312; lines 13-15: CMLAPS 462; lines 16-18: negative control; lines 19-21: CMLAPS 464; lines 22-24: CMLAPS 466; lines 25-27: CMLAPS 467. Lines 28-29: negative control; line 10: positive control; and lines M: 100 bp ladder DNA (Qiagen GelPilot ${ }^{\circledR}$ ).

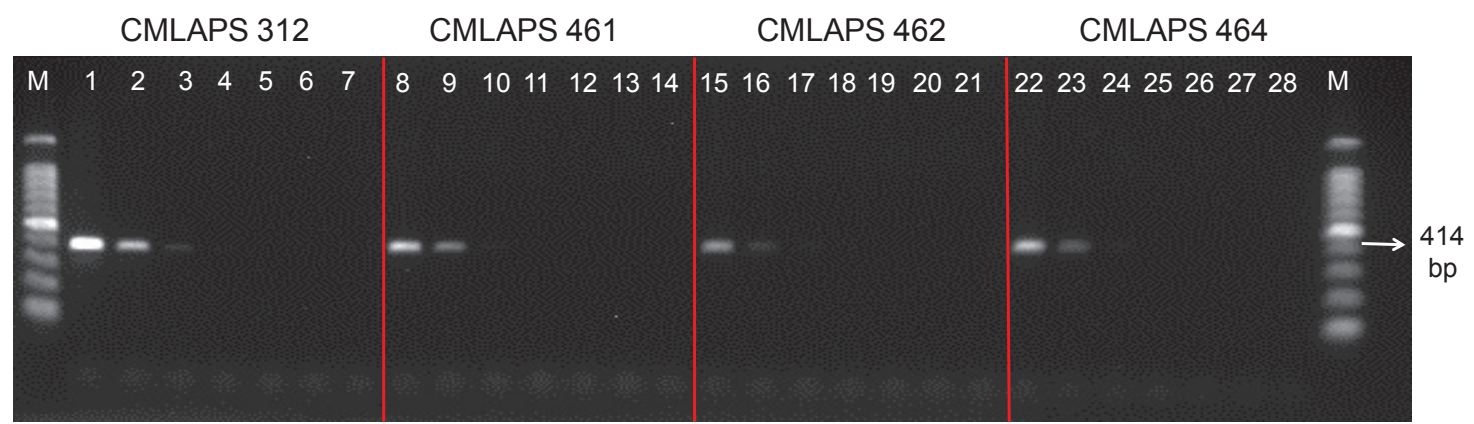

Figure 2. Detection limit of the pair of primers GA4-F/ GA4-R evaluated in PCR with dilutions in series of genomic DNA of 2 ng to $0.2 \mathrm{pg}$ of the different isolates of $C$. cassiicola - lines 2-6: CMLAPS 312, lines 9-13: CMLAPS 461, lines 16-20: CMLAPS 462, lines 23-27: CMLAPS 464. Lines 1, 8, 15 and 22: positive controls. Lines 7, 14, 21 and 28: negative controls. Lines M: 100 bp ladder DNA (Qiagen GelPilot ${ }^{\circledR}$ ).

The pair of primers GA4-F/GA4-R detected C. cassiicola in soybean seeds (Figure 3) with the inoculum potential P1 with incidence levels ranging from $10 \%$ to $100 \%$; in $\mathrm{P} 2$, as of $1 \%$ to $100 \%$; in $\mathrm{P} 3$, the minimum artificial incidence level of $0.25 \%$ was detected. These results indicate the high potential of the conventional PCR technique for detection of $C$. cassiicola soybean seed samples with low incidence, which can be of extreme help in diagnosis and in prevention of the spread of this pathogen from use of seeds that carry it.

Nevertheless, in this type of study, it is important to consider the representative nature of the sample of seeds to be evaluated in routine analyses, keeping in mind that for molecular techniques, the samples analyzed are very small. In this study, in spite of the three replications of DNA extraction, each one with approximately $50 \mathrm{mg}$ of sample, it was not possible to detect the pathogen at all the incidence levels of the different inoculum potentials. Thus, the conventional PCR technique, in spite of representing an advance in routine detection of pathogens in seeds, still confronts challenges, such as the size of the sample to be evaluated, the homogeneity of the lot and the quantity or fungal load that the seed lot has. 


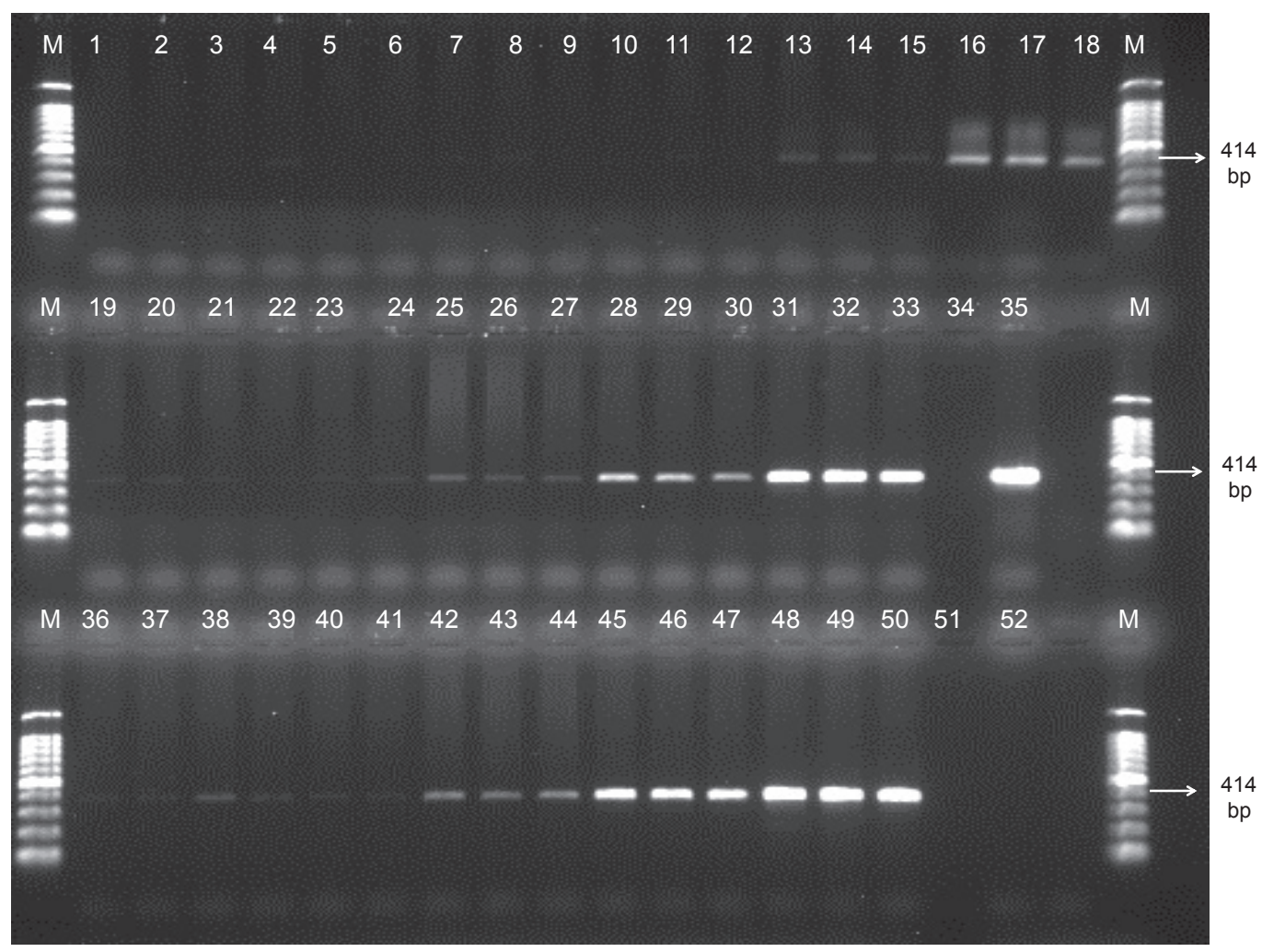

Figure 3. Detection limit of $C$. cassiicola with the pair of primers GA4-F/ GA4-R in soybean seeds, with different incidence levels (IL). Lines 1-3: P0, lines 4-6: P1/ IL 0.25\%; lines 7-9: P1/ IL 0.50\%; lines 10-12: P1/ IL 1\%; lines 13-15: P1/ IL 10\%; lines 16-18: P1/ IL 100\%; lines 19-21: P2/ IL 0.25\%; lines 22-24: P2/ IL 0.50\%; lines 25-27: P2/ IL 1\%; lines 28-30: P2/ IL 10\%; lines 31-33: P2/ IL 100\%; lines 36-38: P3/ IL 0.25\%; lines 39-41: P3/ IL 0.50\%; lines 42-44: P3/ IL 1\%; lines 45-47: P3/ IL 10\%; lines 48-50: P3/ IL 100\%. Lines 34, 51, and 52: negative control; line 35: positive control; lines M: 100 bp ladder DNA (Qiagen GelPilot $\left.{ }^{\circledR}\right)$.

Analyses of seeds from two soybean cultivars naturally infected by C. cassiicola, when macerated without any type of previous incubation, and their respective DNAs extracted and subjected to PCR, exhibited positive results only for two seed samples. When these seeds were incubated prior to extraction of DNA (BIO-PCR), among all the samples, amplifications of DNA were observed in at least two replications in electrophoretic analysis, showing the presence of $C$. cassiicola in all the isolate/cultivar associations (Table 3 ). In spite of only one positive replication being sufficient to consider the presence of the pathogen in a seed lot, it is important to highlight that the bands generated need to be visible so as not to generate questions in routine analysis.

From these results, it is evident that the primers GA4-F and GA4-R are efficient in specific detection of C. cassiicola and that previous incubation of the seeds, or BIO-PCR, lends greater reliability in regard to detection of the pathogen, even when it is in low concentrations. It should be remembered that lower sensitivity of conventional PCR in detecting the pathogen in seeds with lower inoculum potential, which corresponds to contact of seeds with the fungus for the period of 36 hours, and with minimum incidence of $10 \%$, can be increased by means of previous incubation of seeds in a substrate with water restriction for additional periods from one to three days. This procedure can be adopted as part of the protocol of detection of the fungus in question in laboratory analyses.

This same type of result has been reported for other species of Stenocarpella associated with maize seeds, where the PCR technique, although with detection still at the genus level, has proven to be promising (Barrocas et al., 2012). However, it should also be highlighted that a positive result revealed by a molecular technique, like PCR, does not indicate the viability of the organism detected and, thus, biological tests should be applied as well, for greater certainty in these types of laboratory analyses. 
Table 3. Amplification of genomic DNA of C. cassiicola by PCR with the pair of primers GA4-F/ GA4-R in soybean seeds naturally infected from the region of Rondonopolis, MT, Brazil.

\begin{tabular}{ccc}
\hline Sample & Type of sample & $\begin{array}{c}\text { PCR detection } \\
\text { (positive results/replication) }\end{array}$ \\
\hline 1 & Soybean seeds & $2 / 5$ \\
2 & Soybean seeds & $2 / 5$ \\
3 & Soybean seeds & $4 / 5$ \\
4 & Soybean seeds & $2 / 5$ \\
5 & Soybean seeds & $5 / 5$ \\
6 & Soybean seeds & $5 / 5$ \\
7 & Soybean seeds & $2 / 5$ \\
8 & Soybean seeds & $4 / 5$ \\
9 & Soybean seeds & $2 / 5$ \\
10 & Soybean seeds & $2 / 5$ \\
11 & Soybean seeds & $4 / 5$ \\
12 & Soybean seeds & $2 / 5$ \\
\hline
\end{tabular}

\section{Conclusions}

This study indicates the high potential for use of the conventional PCR technique for detection of C. cassiicola in soybean seed samples.

\section{Acknowledgments}

Our thanks to the CNPq, CAPES, and FAPEMIG for financial support and to Riber Sementes and Fundação Mato Grosso for providing soybean seeds.

\section{References}

ALMEIDA, A. M. R.; FERREIRA, L. P.; YORINORI, J. T.; SILVA, J. F. V.; HENNING, A. A.; GODOY, C. V.; COSTAMILAN, L. M.; MEYER, M. C. Doenças da soja. In: KIMATI, H.; AMORIM, L.; BERGAMIN FILHO, A.; CAMARGO, L. E. A.; REZENDE, J. A. M. (Ed.). Manual de fitopatologia: doenças das plantas cultivadas. 4 ed. São Paulo: Agronômica Ceres, v.2, p.569-588, 2005. http://www.scielo.br/scielo.php?script=sci nlinks\&ref $=000078 \&$ pid $=$ S1806-6690201300040001200002\&lng $=$ pt

BARROCAS, E. N.; MACHADO, J. C.; ALMEIDA, M. F.; BOTELHO, L. S.; VON PINHO, E. V. R. Sensibility of the PCR technique in the detection of Stenocarpella sp. associated with maize seeds. Revista Brasileira de Sementes, v.34, n.2, p.218-224, 2012. http://www.scielo.br/pdf/rbs/v34n2/05.pdf

BISWAS, C.; DEY, P.; SATPATHY, S.; SARKAR, S. K.; BERA, A.; MAHAPATRA, B. S. A simple method of DNA isolation from jute (Corchorus olitorius) seed suitable for PCR-based detection of the pathogen Macrophomina phaseolina (Tassi) Goid. Letters in Applied Microbiology, v.56, n.2, p.105-110, 2013. http://onlinelibrary.wiley.com/ doi/10.1111/lam.12020/epdf
BOTELHO, L. S.; BARROCAS, E. N.; MACHADO, J. C.; MARTINS, R. S. Detection of Sclerotinia sclerotiorum in soybean seeds by conventional and quantitative PCR techniques. Journal of Seed Science, v.37, n.1, p. 55-62, 2015. http://www.scielo.br/pdf/jss/v37n1/2317-1545-jss-v37n1141460.pdf

BRASIL. Ministério da Agricultura, Pecuária e Abastecimento. Regras para análise de sementes. Ministério da Agricultura, Pecuária e Abastecimento. Secretaria de Defesa Agropecuária. Brasília: MAPA/ACS, 2009a. 395p. http:// www.agricultura.gov.br/arq_editor/file/2946_regras_analise_sementes.pdf

BRASIL. Ministério da Agricultura, Pecuária e Abastecimento. Secretaria de Defesa Agropecuária. Manual de Análise Sanitária de Sementes. Brasília: MAPA/ACS. 1.ed, 2009b. 200p. http://www.bs.cca.ufsc.br/publicacoes/ manual_analises_sanitarias.pdf

CHEN, Y. Y.; CONNER, R. L.; GILLARD, C. L.; BOLAND, G. J.; BABCOCK, C.; CHANG, K. F.; HWANG, S. F.; BALASUBRAMANIAN, P. M. A specific and sensitive method for the detection of Colletotrichum lindemuthianum in dry bean tissue. Plant Disease, v. 91, p.1271-1276. 2007. http://apsjournals.apsnet.org/doi/pdf/10.1094/PDIS-91-10-1271

CHEN, Y. Y.; CONNER, R. L.; GILLARD, C. L.; MCLAREN, D. L.; BOLAND, G. J.; BALASUBRAMANIAN, P. M.; STASOLLA, C.; ZHOU, Q. X.; HWANG, S. F.; CHANG, K. F.; BABCOCK, C. A quantitative realtime PCR assay for detection of Colletotrichum lindemuthianum in navy bean seeds. Plant pathology, v.62, n.4, p.900-907, 2013. http://onlinelibrary. wiley.com/doi/10.1111/j.1365-3059.2012.02692.x/epdf

DIXON, L. J.; SCHLUB, R. L.; PERNEZNY, K.; DATNOFF, L. E. Host specialization and phylogenetic diversity of Corynespora cassiicola. Phytopathology, v.99, p.1015-1027, 2009. http://apsjournals.apsnet.org/doi/ pdf/10.1094/PHYTO-99-9-1015

HENNING, A. A.; ALMEIDA, A. M. R.; GODOY, C. V.; SEIXAS, C. D. S.; YORINORI, J. T.; COSTAMILAN, L. M.; FERREIRA, L. P.; MEYER, M. C.; SOARES, R. M.; DIAS, W. P. Manual de identificação de doenças de soja. Londrina: Embrapa Soja (Embrapa Soja Documentos 256), 2005.

KAUSHAL, R. P. Epidemiological aspects of target leaf spot of soybean. Soybean Research, v.7, p.30-36, 2009. http://www.cabdirect.org/print abstract.html?pa $=20113020038$

KOENNING, S. R.; CRESWELL, T. C. Increased occurrence of target spot of soybean caused by Corynespora cassiicola in southeastern United States. Plant Disease, v.90 p. 974,2006 . http://apsjournals.apsnet.org/doi/ abs/10.1094/PD-90-0974C

KONSTANTINOVA, P.; BONANTS, P. J. M.; GENT-PELZER, M. P. E.; ZOUWEN, P.; BULK, R. Development of specific primers for detection and identification of Alternaria spp. in carrot material by PCR and comparison with blotter and plating assays. Mycological Research, v.106, n.1, p.23-33, 2002. http://dx.doi.org/10.1017/S0953756201005160

MACHADO, J. C.; BARROCAS, E. N.; COSTA, L. N.; GUIMARÃES, R. M; MACHADO, C. Uso da técnica de restrição hídrica ou condicionamento osmótico em patologia de sementes. Revisão Anual de Patologia de Plantas (impresso), v.20, p.37-63, 2012.

MICHEL, B. E.; RADCLIFFE, D. A. Computer program relating solute potential to solution composition for five solutes. Agronomy Journal, v.87, n.1, p.131-136, 1995.

MOLOUBA, F.; GUIMIER, C.; BERTHIER, C. Detection of bean seedborne pathogens by PCR. Acta Horticultura, v.546, p.603-607, 2001. http:// www.actahort.org/books/546/546 84.htm 
RÍOS, M. O.; FERNÁNDEZ, O.; CARMONA, M. Detection of Rhynchosporium secalis in barley seeds from Argentina through polymerase chain reaction technique. Fitopatologia Brasileira, v.32, p.415-418, 2007. http://www.scielo.br/pdf/fb/v32n5/v32n5a07.pdf

SAJEESH, P. K.; RAO, M. S. L.; JAHAGIRDAR, S. Molecular detection, transmission and histopathological studies of seed-borne fungal infection of soybean (Glycine $\max$ (L.) Merrill). The Bioscan (Supplement on Plant Pathology) v.9, n.1, p.247-251, 2014. https://www.researchgate.net/profile/ Sajeesh_P_K/publication/270891168

SILVA, W. P. K.; DEVERALL, B. J.; LYON, B. R. Molecular, physiological and pathological characterization of Corynespora leaf spot fungi from rubber plantations in Sri Lanka. Plant Pathology, v.47, p.267-277, 1998. http:// onlinelibrary.wiley.com/doi/10.1046/j.1365-3059.1998.00245.x/epdf

SINCLAIR, J. B.; BACKMAN, P. A. Compendium of soybean disease. 3ed. St.Paul: The American Phytopathological Society, 1989. 104p.

SOARES, R. M.; GODOY, C. V.; OLIVEIRA, M. C. N. Escala diagramática para avaliação da severidade da mancha alvo da soja. Tropical Plant Pathology, v.34, n.5, p.333-338, 2009. http://www.scielo.br/pdf/tpp/v34n5/ v34n5a07.pdf
SOUSA, F. M. G.; BENTES, J. L .S. Variabilidade de isolados de Corynespora cassiicola (Berk. \& Curt.) Wei procedentes do Amazonas, em meios de cultura. Summa Phytopathologica, v.40, n.1, p.84-87, 2014. http:// www.scielo.br/pdf/sp/v40n1/v40n1a14.pdf

SOUSA, M. V.; MACHADO, J. C.; SIMMONS, H. E.; MUNKVOLD, G. P. Real-time quantitative PCR assays for the rapid detection and quantification of Fusarium oxysporum f. sp. phaseoli in Phaseolus vulgaris (common bean) seeds. Plant Pathology, v.64, p.478-488, 2015. http://onlinelibrary.wiley. com/doi/10.1111/ppa.12257/epdf

TESTEN, A. L.; JIMÉNEZ-GASCO, M. M.; OCHOA, J. B.; BACKMAN, P. A. Molecular detection of Peronospora variabilis in quinoa seed and phylogeny of the quinoa downy mildew pathogen in South America and the United States. Phytopathology, v.104, p.379-386, 2014. http://apsjournals. apsnet.org/doi/pdf/10.1094/PHYTO-07-13-0198-R

WALCOTT, R. R. Detection of seedborne pathogens. HortTechnology, v.13, n.1, p.40-47, 2003. http://horttech.ashspublications.org/content/13/1/40.full.pdf + html 